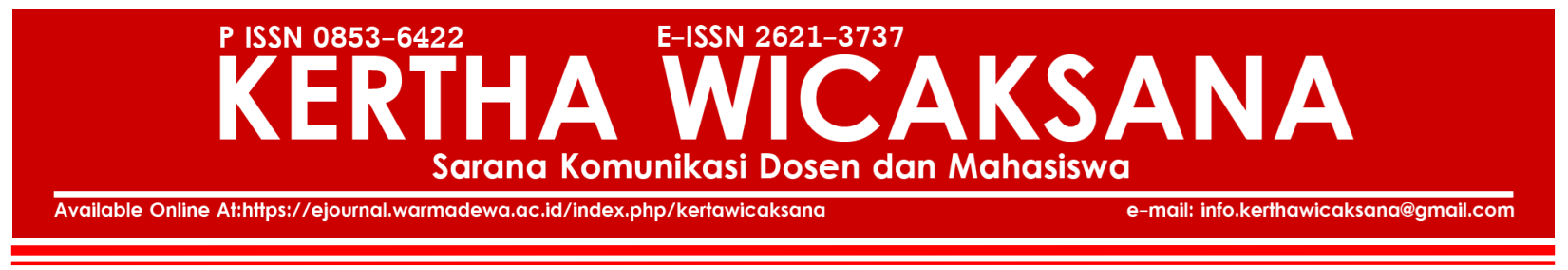

\title{
Penguatan Kewenangan Komisi Pengawas Persaingan Usaha Lewat Putusan Mahkamah Konstitusi (Putusan Mk No.85/Puu-Xiv/2016)
}

\author{
Asmah \\ Universitas Sawerigading, Makassar \\ asmahunsa@yahoo.co.id
}

Published: 30/01/2021

How To Cite:

Asmah. (2021). Penguatan Kewenangan Komisi Pengawas Persaingan Usaha Lewat Putusan Mahkamah Konstitusi (Putusan Mk No.85/Puu-Xiv/2016). KERTHA WICAKSANA: Sarana Komunikasi Dosen dan Mahasiswa. 15 (1). Pp 11 - 17. https://doi.org/10.22225/kw.14.2.1863.77-86

\begin{abstract}
Abstrak
Komisi pengawas persaingan usaha (KPPU) adalah komisi negara yang dibentuk berdasarkan amanat Undang-Undang No 5 Tahun 1999 tentang larangan praktek monopoli dan persaingan usaha tidak sehat. yang mengingkan adanya persaingan yang sehat dalam bidang usaha. KPPU bertugas sebagai penegak hukum terhadap praktek persaingan usaha, pengawasan merger dan pemberi saran kebijakan pemerintah. Dalam pelaksanaan tugasnya komisi ini berwenang untuk menyusun pedoman. Dalam pelaksanaan tugas yang diemban KPPU sebagai amanah UU untuk membentuk perekonomian indonesia yang efisien dengan menciptakan iklim usaha yang kondusif, memberikan kepastian hukum agar setiap pelaku usaha memiliki kesempatan yang sama dalam berusaha serta terciptanya efektifitas dan efisiensi dalam kegiatan usaha. Dalam rumusan masalah sejauhmana penguatan Komisi Pengawas Persaingan Usaha sebagai Lembaga penegak hukum dan lembaga independen yang dibentuk berdasarkan amanah UU NO.5 tahun 1999 dengan setelah Putusan Mahkamah konstitusi menjadi lebih terarah dalam penegakan hukum persaingan usaha di indonesia Penelitian ini menggunakan penelitian normatif empiris dengan pendekatan kasus dan perbandingan lewat putusan yang pernah ada. Kesimpulan penguatan KPPU setelah adanya putusan Mahkamah konstitusi, sebagai sebuah lembaga penegak hukum yang oleh UU diberi amanah dalam penyelidikan, penuntutan serta putusan, kppu disebuat sebagai lembaga qauasi judicial karena bisa memutus terhadap suatu perkara yang diselidikinya.
\end{abstract}

Kata Kunci: Komisi Pengawas Persaingan Usaha; Kewenangan; lembaga Negara

\begin{abstract}
Business competition supervisory commission (KPPU) is a state commission formed based on the mandate of Law No. 5 of 1999 concerning the prohibition of monopolistic practices and unfair business competition. which wants healthy competition in the business sector. KPPU has the duty to enforce the law on the practice of business competition, supervise mergers and provide government policy advice. In carrying out their duties, the commission is authorized to draw up guidelines. In carrying out the tasks carried out by KPPU as the mandate of the Law to establish an efficient Indonesian economy by creating a conducive business climate, providing legal certainty so that each business actor has the same opportunity in trying and creating effectiveness and efficiency in business activities. In the formulation of the problem of the extent to which the strengthening of the Business Competition Supervisory Commission as a law enforcement agency and an independent institution established under the mandate of Law NO.5 of 1999 after the Constitutional Court's Decision becomes more directed in the enforcement of business competition law in Indonesia This research uses empirical normative research with case approaches and comparisons through existing decisions. The conclusion of the strengthening of the KPPU after the Constitutional Court's decision, as a law enforcement agency which was given the mandate in the investigation, prosecution and decision, KPPU was made as a judicial qauation institution because it could decide on a case investigated.
\end{abstract}

Keywords: Commission for the Supervision of Business Competition; Authority; State institutions 


\section{PENDAhuluan}

Dalam perubahan ke empat (Empat) undangundang Dasar Negara Republik Indonesia dijelaskan dalam Pasal 33 (1) perekonomian disusun sebagai usaha bersama berdasar atas dasar kekeluargaan (2) cabang-cabang produksi yang penting bagi negara dan yang menguasai hajat hidup orang banyak dikuasai oleh negara (3) Bumi air dan kekayaan alam yang terkandung di dalamnya dikuasai oleh negara yang dipergunakan untuk sebasar-besarnya kemakmuran rakyat (4) perekonomian nasional diselenggarakan berdasar atas demokrasi ekonomi dengan prinsip kebersamaan, efisensi keadilan, berkelanjutan, berwawasan lingkungan, kemandirian, serta dengan menjaga keseimbangan kemajuan dan kesatuan ekonomi nasional, (5) ketentuan lebih lanjut mengenai pelaksanaan pasal diatur dalam Undang-Undang.

Mengenai ketentuan dalam UUD Negara Republik Indonesia tersebut sangat jelas disebutkan bahwa perekonomian nasional diselenggarakan berdasar atas demokrasi ekonomi dengan prinsip kebersamaan untuk efisiensi keadilan demi usaha yang adil bagi semua kalangan tanpa adanya sekat dalam dunia usaha dan adanya rasa keadilan dalam berusaha untuk kesejahteraan sebagaimana tujuan dari UU No.5 Tahun 1999 tentang larangan praktek monopoli dan persaingan usaha tidak adalah untuk memberikan kesejahteraan rakyat secara menyeluruh

Komisi pengawas persaingan usaha (KPPU) Republik Indonesia yang merupakan lembaga Independen yang mempunyai tugas sebagai pengawal persaingan usaha dan lembaga penegak hukum, yang bertanggung jawab kepada Presiden dan DPR dalam mengemban amanah amanat UU NO 5 tahun 1999 tentang larangan praktek monopoli dan persaingan usaha tidak sehat, secara resmi berdiri sejak ditetapkannya 11 orang anggota KPPU oleh Presiden Abdurrahman wahid melalui Keppres No.162/M/2000.

Latar belakang lahirnya UU N0. Tahun 1999 adalah kondisi masyarakat yang belum mampu berpartisipasi dalam peluang usaha yang ada, perkembangan usaha swasta diwarnai oleh berbagai bentuk kebijakan yang kurang tepat, adanya hubungan antara pengambil keputusan dengan para pelaku usaha, para pengusaha yang dekat elit kekuasaan mendapatkan kemudahan yang berlebihan, kurangnya daya saing pelaku usaha dipasaran dalam dan luar negeri, kebutuhan adanya peraturan mengenai persaingan usaha yang sehat, minimnya pelaku usaha baru yang berperan pada perekonomian indonesia. (Kuliah umum dan materi TOT KPPU 2018)

Lahirnya KPPU adalah untuk menjaga persaingan yang sehat dan atas desakan dari berbagai pihak bahwa indonesia memerlukan suatu aturan tentang persaingan dan jaminan usaha yang adil bagi semua kalangan sehingga investasi bisa masuk di indonesia yang pada saat tahun 1999 masih terkena krisis moneter, lahirnya KPPU sebagai upaya pemerintah pada saat itu adalah untuk menjawab tantangan dari berbagai pihak untuk adanya sebuah lembaga yang independen yang mengawal persaingan usaha di Indonesia

Konstitusi mengamanatkan negara mewujudkan kesejahteraan yang termaktub dalam 14 pasal Konstitusi 1945, namun dalam realitas empirisnya seakan tidak memiliki kekuatan membentuk masyarakat yang sejahtera (Elviandri, Dimyati, \& Absori, 2019). Dalam konsep negara kesejahteraan dengan tujuan untuk memajukan kesejahteraan umum, sebagaimana tujuam utama dari sebuah negara yang tertuang dalam peraturan Perundang-Undangan yang berlaku semata mata adalah untuk memberikan rasa nyaman dan aman bagi warganya terutama dalam kehidupan dan kelangsungan ekonomi suatu negara lewat usaha yang dilakukan oleh warga negaranya dan adanya keadilan untuk membuka usaha yang sama

Bidang pendidikan, misalnya UUD 1945 bukan hanya secara normatif mengamanatkan kepada pemerintah untuk mengusahakan dan menyelenggarakan satu sistem pendidikan nasional serta memajukan ilmu pengetahuan dan teknologi, tetapi juga menegaskan bahwa pendidikan merupakan hak konstitusional setiap warga negara dan mewajibkan setiap warga negara untuk mengikuti pendidikan dasar sembari mewajibkan pemerintaha membiayainya (Palaguna, 2019) sedangkan dalam kesejahteraan ekonomi dalam sebuah negara telah terjamin dalam UUD Negara Republik Indonesia 1945 sehingga prinsip dan aturan yang ada sangat jelas

Sebagai negara hukum Indonesia Friedich Julius dalam Buku Bachrul Amiq, memberikan empat unsur utama yang harus terdapat dalam Rechstaats meliputi: pengakuan dan perlindungan terhadap Hak-hak Asasi manusia, pemisahan kekuasaan Negara berdasarkan prinsip trias politica, penyelenggaraan pemerintahan menurut Undang-Undang (wetmatigbestur), dan adanya 
peradilan administrasi Negara. Senada dengan pendapat tersebut H.D.Van Wijk dan Konjibenbelt mengemukakan unsure rechstaat sebagai berikut: pemerintahan menurut hukum (Wetmatiq Bestur), hak-hak asasi, pembagian kekuasaan dan pengawasan oleh kekuasaan peradilan. (Bachrul Amiq. 2010:45-47)

Konsep Rechstaat sesungguhnya bukan satusatunya konsep tentang Negara hukum. Konsep Rechstaats lahir dan berkembang di Negaranegara Eropa Kontinental, sementara itu Negaranegara Anglosaxon di Inggris berkembang konsep Rule of law. Berbeda dengan konsep Rechstaats yang tumbuh secara revolusioner sebagai bentuk keinginan membatasi kekuasaan pemerintah, sebaliknya Rule of Law lahir secara evolusioner dalam kerangka meningkatkan fungsi peradilan sebagai perwujudan asas supremasi hukum. A.V. Dicey mengemukakan unsure-unsur Rule Of law sebagai berikut: Supremacy Of law, eguality before the law, and constitution based on Individual right. Likadja mengatakan bahwa, pendekatan rule of law diperlukan untuk membuat konsep negara hukum (rechstaat) menjadi lebih dinamis dan mampu menghadapi dinamika perubahan yang terjadi di masyarakat, serta membuat hukum lebih otonom dari intervensi otoritaslainnya semisal politik (Likadja, 2015)

Konsep negara kesejahteraan dan negara hukum seharusnya melihatdari sebuah relaita suatu bangsa, sebagai bangsa Indonesia dengan berdasar hukum dan Pancasila seharusnya negara kesejahteraan bukan suatu konsep tapi telah dijalankan sebagaimana bunyi sila Ke 5 yaitu Keadilan sosial bagi seluruh rakyat indonesia, maksud tersebut dapat dipahami sebagai maknna secara luas, adil dalam bernegara, dalam menjalankan hukum serta dalam berusaha semua punya kesempatan yang sama.

Adanya gugatan dari masyarakat tentang Frasa atau "pihak lain "dalam penggunaan Pasal 22, 23 dan pasal 24 dengan Pasal 1 angka 8 UU No.5 Tahun 1999. Di satu sisi, Pasal 22, Pasal 23, dan Pasal 24 UU No. 5 Tahun 1999 mengunakan Frasa "pihak lain" yang mempunyai makna umum sehingga membuka berbagai macam penafsiran. Di sisi lain, Pasal 1 angka 8 UU No.5 Tahun 1999 secara tegas menaytakan bahwa persekongkolan hanya terjadi antara pelaku usaha dengan pelaku usaha lainnya. Meskipun Frasa "pihak lain" dapat mengacu pada Pasal 1 angka 8 UU No.5 Tahun 1999, namun penggunaan frasa "pihak lain" dipandang tidak memberikan kepastian hukum dan rentan untuk di tafsirkan secara subjektif dengan memperluas makna dari frasa "pihak lain" dengan demikian guna memberikan kepastian hukum, Mahkamah dapat memberikan penafsiran konstitusional terhadap frasa "pihak lain" dalam psal-pasal aquo yakni pelaku usaha lain

Pendapat dan penggunaan frasa "pihak lain dalam pasal 22,pasal 23, dan pasal 24 serta Pasal 1 angka 8 UU No.5 Tahun 1999 adaalh suatu hal yang di maksudkan sebagai bentuk pencegahan dalam Pasal tersebut, dalam sebuah peraturan perundnag-undangan dimulai dari penelitian dan naskah akademik kemudian menjadi sebuah UU dan berlaku di masyarakat adalah untuk memberikan kepastian hukum dan dapat mencegah terjadinya suatu pelanggaran dari setiap orang yang membaca putusan tersebut.

Dalam buku Ilmu perundang-undangan menurut The Liang Gie, bahwa asas adalah suatu dalil umum yang dinyatakan dalam istilah umum tanpa menyarankan cara khusus mengenai pelaksanaannya yang diterapkan pada serangkaian perbuatan untuk menjadi petunjuk yang tepat bagi perbuatan itu (Astomo, 2018).

Penguatan kppu pasca putusan Mahkamah konstitusi No.85/PUU-XIV/2016 setelah penguatan penggunaan frasa lain yang tidak bertentangan dengan UUD Negara Republik Indonesia dalam pasal 22, Pasal 23, Pasal 24 dan Pasal 1 angka 8 UU No.5 Tahun 1999. Komisi Pengawas Persaingan Usaha (KPPU) memiliki kewenangan memberikan saran dan pertimbangan atas kebijakan pemerintah yang mengarah pada persaingan usaha tidak sehat, melakukan perkuatan di PP No.57/2010, KPPU memiliki kewenangan untuk menerima dan mengevaluasi merger yang dinotifikasi dan dikonsultasikan, KPPU memiliki kewenangan menyelidiki, memeriksa dan memutuskan dugaan pelanggaran persaingan usaha tidak sehat oleh pelaku bisnis, memiliki kewenangan untuk mengawasi dan menegakkan hukum atas pelaksanaan kemitraan antara pelaku besar dengan UMKM.

Frasa dalam kamus bahasa Indonesia adalah gabungan dua kata atau lebih yang bersifat non predikat (misal gunung tinggi disebut frasa karena merupakan konstruksi nonprediktif. (Kamus Bahasa Indonesia, 2007:321)

Dengan adanya putusan dari mahkamah konstitusi menjadikan KPPU sebagai lembaga 
yang satu- satunya lembaga yang bisa sebagai penyidik, pemeriksa sekaligus memutus setiap perkara persaingan usaha sebagaimana amanat dari UU No. 5 Tahun 1999 Pasal 35 dan Pasal 36 sehingga penggunaan frasa "pihak Lain dalam penegakan hukum persaingan usaha yang menimbulkan banyak penafsiran dari berbagai pihak, dengan adanya putusan mahkamah konstitusi memberikan ruang dan dasar hukum bagi KPPU bahwa frasa "pihak lain " tersebut bisa memberikan kekuataan baru bagi KPPU dalam pengumpulan bukti yang selama ini masih kurang karena kewenangan dari KPPU masih dibatasi terutama dalam penyadapan sehingga dengan putusan dari Mahkamah Konstitusi tersebut memberikan penguatan lembaga KPPU .

Berdasarkan uraian tersebut maka dalam artikel ini penulis akan mengkaji mengenai bagaimana seharusnya pengaturan kewenangan KPPU setelah putusan Mahkamah Konstitusi.

\section{METODE}

Penelitian ini adalah penelitian normatif empiris (applied law research) dengan pendekatan kasus dan pebandingan hasil putusan dan berbagai dokumen dan norma kaidah aturan perundang-undangan serta putusan putrusan pengadilan, Penelitian hukum normatif berupa perilaku hukum dengan mengkaji putusan Mahkamah Konstitusi dan bahan-bahan hukum lainnya yang secara langsung berkaitan dengan berkas. Penelitian empiris penelitian hukum menggunakan studi berupa kasus hukum empiris berupa perilaku masyarakat, dan implikasi kepada instansti terkait yaitu KPPU setelah keluarnya Putusan Mahkamah Konstitusi No.85/PUU$\mathrm{XIV} / 2016$.

\section{III.HASIL DAN PEMBAHASAN}

\section{Kedudukan KPPU Dalam Kelembagaan Negara Menurut $U \boldsymbol{U}$}

Dalam perkembangan kehidupan bernegara di berbagai belahan dunia di Eropa sebelum abad ke 19, timbul revolusi dari warga masyarakat pada masa itu bahwa negara hanya sebagai pengawas atau penjaga keamanan saja, namun hal ini tidak berlangsung lama, dengan berbagai tuntutan masyarakat tentang ekonomi, politik dan pemerintahan pada abad ke 20 muncul doktri tentang welpare state atau negara kesejahteraan, bahwa pentingnya pembentukan lembagalembaga negara untuk hal tersebut.

Semenjak reformasi, UUD Negara Republik
Indonesia 1945 telah mengalami empat kali perubahan yang berakibat pada berubahnya sendi -sendi ketatanegaraan, salah satu hasil yang paling mendasar adalah perubahan supremasi MPR menjadi supremasi konstitusi, pasca reformasi indonesia tidak mengenl istilah "lembaga Tertinggi Negara", untuk kedudukan MPR sehingga seluruh lembaga negara sederajat kedudukannya dalam sistem Check and Balances, seiring itu konstitusi ditempatkan sebagai hukum tertinggi yang mengatur dan membatasi kekuasaan lembaga-lembaga negara dalam penyelenggaraan negara. Berdasarkan putusan MK dalam perkara No 005/PUU-I/2003 tentang perkara permohonan pengujian UU No 32 Tahun 2002 tentang penyiaran terhadap UUD 1945. MK menjelaskan bahwa "Lembaga Negara" tidak sama dengan "lembaga negara " (dengan huruf kecil) olehnya penulis berpendapat bahwa KPPU yang dibentuk berdasarkan amanah UU No 5 Tahun 1999 memiliki kedudukan yang signifikan dalam sistem ketatanegaraan Republik Indonesia, terutama dalam pencapaian tujuan penyelenggaraan pemerintahan yaitu mendorong pembangunan perekonomian nasional dengan meningkatkan efisiensi perekonomian nasional melalui penerapan prinsip-prinsip persaingan usaha yang sehat dalam kegiatan usaha.

Berdasarkan fungsi yang diemban tersebut sebagaimana amanah UU No 5 Tahun 1999, maka KPPU adalah sebuah lembaga Negara penunjang "state auxiliary organ" atau "auxiliary institusion" sebagai lembaga negara yang bersifat penunjang.KPPU sebagai lembaga pengawas untuk mengawal pelaksanaan UU No 5 Tahun 1999, maka sebagai lembaga state auxiliary tidak berada baik dibawah ekesekutif, legislatif, yudikatif. KPPU merupakan lembaga yang independen yang mengawasi adanya persaingan usaha tidak sehat dan praktek monopoli. kedudukan KPPU dalam sistem ketatanegaraan Indonesia adalah di sebut sebagai state auxiliary organs atau lembaga negara penunjang atau khusus yang menangani permasalah persaingan usaha tidak sehat. Pembentukan KPPU berdasarkan amanah UU No 5 Tahun 1999.

Sebagai lembaga negara khusus atau lembaga negara penunjang mempunyai tugas dalam mengawal dan melaksanakan UU No 5 Tahun 1999 bisa berjalan sesuai dengan yang diharapkan adalah menjaga persaingan usaha yang sehat demi terciptanya kesejahteraan dalam masyarakat. Pada hakikatnya, keberadaan KPPU dalam melaksanakan UU No 5 Tahun 1999 adalah 
mengupayaan secara optimal terciptanya persaingan usaha yang sehat dan efektif pada suatu pasar tertentu yang mendorong agar pelaku usaha melakukan efisiensi agar mampu bersaing dengan para pesaingnya.

Keberadaan UU persaingan yang sehat yang berasaskan demokrasi ekonomi juga harus memperhatikan keseimbangan antara pelaku usaha dan kepentingan masyarakat. Dengan menyimak dan melihat pendapat dari Roscoe Pound, kehadiran UU No 5 Tahun 1999 dan KPPU sebagai lembaga yang dibentuk dari UU tersebut, maka kehadiran KPPU seperti " a tool of social control and a tool of social engineering. Hukum hukum mempunyai fungsi sebagai alat perekayasa sosial, harus mampu melindungi tiga kepentingan dasar, kepentingan umum, dan kepentingan sosial.

Sebagaimana dalam Undang-Undang No 12 Tahun 2011 tentang pembentukan peraturan perundang-undangan tercantum dalam hirarki bahwa peraturan perundang-undangan adalah setingkat atau sejajar dengan Undang-Undang, hal mendasar yang membedakan adalah kalau Undang-Undang bisa inisiatif dari DPR dan Presiden sedangkan Perpu merupakan hak prerogatif Presiden. Jadi KPPU sebagai lembaga negara pendukung atau state auxiliary organ tidak dapat mengeluarkan peraturan perundangundangan yang menjadi kewenangan Presiden.

KPPU juga telah diatur Dalam Pasal 35, dan Pasal 36 UU No 5 Tahun 1999 dan Kepres No 75 Tahun 1999 jo Perpres No 80, KPPU telah membentuk sekretariat dan telah ditetapkan dengan keputusan KPPU.

Logika penerbitan Perpu juga dapat dilihat sebagai berikut:

\section{Adanya suatu keadaan bahaya atau genting}

Keadaan bahaya ini dapat mengancam keselamatan warga negara atau bangsa jika pemerintah tidak segera bertindak atau melakukan suatu tindakan yang nyata.

Karena sifatnya yang mendesak, maka segera di butuhkan sebuah payung hukum dari pemerintah karena jika menunggu mekanisme Undang-Undang dengan DPR maka akan membutuhkan waktu yang relatif lama. Jika dilihat dari tiga kriteria diatas KPPU tidak termasuk dalam ketiga tersebut, melihat bahwa KPPU sekarang sudah di ketahui oleh masyarakat luas lewat sosialisasi dan perwakilan kantor daerah di beberapa Provinsi serta lewat Forum dosen persaingan usaha (FDPU) yang lebih mensosialisasikan lagi keputusan dari KPPU, begitupun dengan dunia persaingan usaha sudah semakin berkembang di masyarakat lewat akademisi maupun pakar hukum dalam kegiatan kuliah umum maupun TOT oleh KPPU.

walaupun ada terkendala dalam status kepegawaian dapat dibuatkan sebuah peraturan dari komisi dan dirapatkan bersama dalam penentuan dan kebijakan pada organisasi kepegawaian kppu

Independensi kppu sebagai lembaga quasi judisial review

Kewenangan lain sering di sebut sebagai Quasi Judicial review karena KPPU memiliki kewenangan untuk memeriksa dan memutus suatu putusan hukum atas tindakan perjanjian yang melanggar Pasal 36 UU No. 5 Tahun 1999. Tetapi KPPU tidak termasuk dalam lingkup Peradilan.

Tentang kekuasaan kehakiman dan UU No 5 tahun 2004 tentang Mahkamah Agung:

Keberatan atas putusan KPPU dapat diajukan ke pengadilan Negeri.sebagai Judex Facti yang memeriksa kenyataan sebagai alas perkara dan kemudian menerapkan fakta-fakta tersebut terhadap hukum yang menjadi landasan yuridis perkara.

Putusan KPPU merupakan hukum karena memiliki kekuatan eksekutorial (Pasal 44, 46) tidak termasuk dalam PTUN.

MA sebagai Judex juris karena merupakan peradilan tingkat kasasi terhadap putusan PN dan hanya memriksa aspek penerapan hukum. dalam pasal 30 UU No 5 Tahun 1999, KPPU di bentuk merupakan komisi yang bebas dan independen bebas dari pengaruh kekuasaan manapun dan bertanggung jawab kepada Presiden.

KPPU mempunyai Fungsi penegakan hukum tetapi bukan bagian dari peradilan. KPPU tidak berwenang menjatuhkan sanksi pidana dan perdata, tetapi sanksi administratif.

Kedudukan KPPU dalam sistem peradilan, fungsi utama adalah mengawal dan menciptakan demokrasi ekonomi dan persaingan usaha yang sehat bagi seluruh warga Negara Indonesia untuk berpartisipasi dalam proses produksi dan pemasaran barang dan jasa dalam iklim usaha yang sehat dan efektif, efisien sehingga 
mendorong pertumbuhan ekonomi dan pasar yang sehat.

Fungsi dan idealnya KPPU di Indonesia, selain tugas utamanya sebagaimana dalam Pasal 35 UU No 5Tahun 1999 dan wewenangnya KPPU dalam Pasal 36 UU No 5 Tahun 1999.

Fungsi KPPU yang ideal lainnya dapat berupa Penegakan Hukum, dalam artian sebagai investigasi terhadap setiap kasus dan laporan dari masyarakat jika terjadi suatu pelanggaran dalam persaingan usaha tidak sehat.

Pencegahan atau upaya preventif dalam istilah hukum pidana, yaitu dengan melakukan pengkajian setiap persoalan yang berkaitan persaingan usaha, melakukan penelitian yang melibatkan unsur akademisi perguruan tinggi dan pakar hukum, serta melakukan monitoring terhadap pelaku usaha yang berada di wilayahnya serta melakukan sosialisasi yang maksimal kepada pemerintah Provinsi dan Pemerintah Kotamadya dan Daerah dalam hal mensosialisasikan UU No 5 Tahun 1999, sehingga Perda yang dikeluarkan oleh Pemprov dan Pemda tidak bertentangan dengan UU No 5 Tahun 1999.

Penataan tata usaha dan kepegawaian dalam mendukung pelaksanaan KPPU dari dalam dan penyiapan pelaksanaan internalisasi nilai persaingan usaha yang sehat di wilayah kerja KPPU pusat dan KPPU KPD.

\section{Pendekatan penegakan hukum oleh KPPU}

Penegakan hukum yang dilakukan KPPU di Indonesia selama ini adalah dengan melalui pendekatan Rule of reason dan Per se Illegal, artinya bahwa rule of reason untuk menyatakan bahwa suatu perbuatan yang dianggap melakukan praktek monopoli dan persaingan usaha tidak sehat, dalam melakukan penyelidikan dan penyidikan KPPU senantiasa mempertimbangkan keadaan dalam kasus tersebut, apabila dalam memutuskan harus berhati-hati apakah persaingan yang dimaksud menunjukkan adanya perbuatan tidak adil maupun melawan hukum.

Dalam penyusunan dan penegakan kebijakan persaingan adalah untuk menjaga perimbangan antara pemenuhan prinsip keadilan di satu sisi dan prinsip kepastian di ssis lain, sehingga putusan yang di hasilkan oleh KPPU dapat menentukan dampak dalam hukum persaingan usaha Sedangkan dalam per se illegal secara pasti sudah melanggar persaingan dengan menghalangi atau melumpuhkan persaingan yang sehat dalam masyarakat.

Dalam kenyataan dan dalam kasus-kasus persaingan usaha yang terjadi, penggunaan pendekatan tersebut harus tepat dan hati-hati karena tidak mudah diterapkan, karena tidak semua orang mempunyai persepsi yang sama terhadap terhadap kedua pendekatan tersebut. Berbagai macam metode dan pendapat para ahli hukum persaingan serta praktisi tentunya menambah kehati hatian dalam penggunaan pendekatan tersebut.

Penggunaan dan pengenaan dalam setiap pasal dalam UU No.5 tahun 1999 menggambarkan bentuk pendekatan per se illegal melalui beberapa pasal yang sifatnya imperatif dan interperetasi yang memaksa sehingga dalam penggunaan kata Frasa "penyetaaan dalam pasal 22, 23,24 dan pasal 1 angka 8 multi tafsir dan menimbulkan penafsiran dalam berbagai pengenaannya sehingga menimbulkan judicial review ke Mahkamah Konstitusi.

Dalam pengenaan hukum persaingan usaha beberapa negara memberlakukan hal yang berbada dan tidak sama terhadap tafsiran perse illegal dan per reason hal ini karena dipengaruyhi oleh pertimbangan-pertimbangan kepatutan dan keadilan serta budaya dan kebijakan arah ekonomi suatu bangsa namun secara universal memberlakukan pendekatan yang sama yaitu per reason dan per se illegal.

Sedangkan kewenangan yang diberikan UU kepada KPPU tentunya sesuai dengan pasal 36

Meminta bantuan penyidik untuk menghadirkan setiap orang yang tidak bersedia memenuhi panggilan komisi.

Meminta keterangan dari instansi pemerintah

Mendapatkan, meneliti dan atau menilai surat dokumen, dan atau alat bukti

Memutuskan dan menetapkan ada atau tidak adanya kerugian di pihak pelaku usaha atau masyarakat.

Memberitahukan putusan KPPU kepada Pelaku usaha yang diduga melakukan praktek monopoli dan atau persaingan usaha tidak sehat.

Menjatuhkan sanksi berupa sanksi administratif.

Untuk memaksimalkan sanksi pidana tambahan dalam Pasal 49 dengan menunjuk 
ketentuan Pasal 10 Kitab Undang-Undnag hukum Pidana, berupa pencabutan izin usaha dapat dilakukan kepada pelaku usaha yang melanggar UU No 5 Tahun 1999. Memaksimalkan larangan kepada pelanggaran terhadap undang-undang ini untuk menduduki jabatan direksi atau komisaris. Penghentian kegiatan atau tindakan tertentu yang menyebabkan timbulnya kerugian kepada pihak lain.

\section{Kedudukan Komisi Pengawas Persaingan Usaha} setelah keluar Putusan Mahkamah Konstitusi

Kedudukan KPPU setelah putusan MK Nomor 85/PUU-XIV/2016, terutama setelah diajukan judisial reviaw atas pasal 22,23 dan 24 dan Pasal 1 angka 8UU No 5 Tahun 1999

Dengan adanya putusan Mahkamah tersebut membuat kewenangan KPPU yang selama ini ada dalam pasal 35 UU No.5 Tahun 1999 menjadi lebih kuat terutama dalam penguatan kelembagaan tidak hanya sebagai penegak hukum, mealui tindakan penanganan perkara yang ditangani dan pelaksanaan upaya-upaya lanjutan yang terkait dengan ekstistensi dan pelaksanaan upaya-upaya lanjutan yang terkait dengan eksistensi dan pelaksanaan penetapan dan putusan atas suatu perkara, yaitu tindakan monitoring putusan dan upaya litigasi. Tugas dari KPPU selain sebagai penegak hukum yang menjadi tugas utama juga sebagai pemberi saran kepada pemerintah dan pemerintah daerah dalam pembentukan Perda.

Berbagai tugas dan wewenang yang ada dalam UU telah dilakukan untuk membuat hukum persaingan usaha di Indonesia menjadi lebih maju khususnya di kawasan Asean, yang banyak menjadi contoh dalam penegakan hukum persaingan usaha yang telah memenangkan 359 perkara dan jumlah perkara tender sebanyak 250 dari tahun ke tahun perkembangan kasus yang di selesaikan oleh KPPU mengalami peningkatan, sampai dengan awal tahun 2018, perkara yang ditangani atas dasar laporan yang disampaikan kepada KPPU sebanyak 300 selanjutnya, perkaran yang ditangani atas iniseatif KPPU adalah sebanyak 43 dan 16 perkara keterlambatan notifikasi merger dan akuisisi.

\section{IV.SIMPULAN}

Pengaturan kewenangan KPPU setelah keluarnya putusan Mahkamah Konstitusi menjadi lebih baik khususnya dalam pengenaan Pasal-Pasal yang dianggap oleh sebagian masyarakat kurang demokratis dalam bidang ekonomi dan kurang adil dalam bidang hukum khususnya Pasal 22,23,24 dan Pasal 1 angka 8 UU No.5 Tahun 1999 adanya pengenaan kata Frasa atau penyertaan pihak lain dengan adanya keputusan MK Nomor 85/PUU-XIV/2016, menjadikan KPPU lebih terarah dalam menegakkan hukum persaingan usaha di Indonesia, mengingat persoalan peresekonkolan tender merupakan perkara yang paling banyak di tanganioleh KPPU selama ini.

\section{DAFTAR PUSTAKA}

Astomo, P. (2018). Ilmu perundang-Undangan teori dan praktik di Indonesia. Jakarta: Rajawali Grafindo.

Elviandri, Dimyati, K., \& Absori. (2019). Quo Vadis Negara Kesejahteraan: Meneguhkan Ideologi Welfare State Negara Hukum Kesejahteraan Indonesia. Mimbar Hukum, 21(2), 252-266. Retrieved from https://jurnal.ugm.ac.id/jmh/ article/download/32986/25629

Likadja, J. A. (2015). Memaknani Hukum Negara (Lay Through State) dalam Bingkai Negara Hukum (Rechtstaat). Hasanuddin Law Review, 1(1). Retrieved from http://pasca.unhas.ac.id/ojs/ index.php/halrev/article/

download/41/40\#: :text=Konsep rechtstaat berpedoman pada hukum,namun juga yang tidak tertulis.

Palaguna, I. D. G. (2019). walfare state vs globalisasi. Jakarta: Rajawali Grafindo. 